\title{
特集 生体膜と人工膜の接点
}

\section{精妙な生体膜のはたらきとナノバイオマテリアルの開発}

\section{藤本啓二}

慶応義塾大学大学院 理工学研究科 生命理工学専修 ₹223-8522 神奈川県横浜市港北区日吉3-14-1

\section{Development of Nano-biomaterials Involved in Exquisite Functions of Biomembranes}

\author{
Keiji Fujimoto \\ Department of Applied Chemistry, Faculty of Science and Technology, Keio University \\ 3-14-1 Hiyoshi, Kohoku-ku, Yokohama 223-8522, Japan
}

\begin{abstract}
Biological and biophysical understanding of cellular functions and machinery will provide a variety of insights into design and synthesis of materials and devices. For instance, shielding of the cell surface can block some of cellular recognition processes and is a useful technique to protect cells and tissues against the harmful substances. By using water-soluble and nonionic polymers having a lipophilic anchor group at one end, polymer chains were attached to a cell surface through the hydrophobic interaction. Alternatively, polymer chains could be chemically linked to membrane proteins or saccharides. Furthermore, cell modification could be carried out using polymer chains with affinities such as RGD-integrin. In all the cases, activation of modified cells was suppressed when they met with relatively large materials such as a tissue culture dish and a micrometer-sized latex particle. Another cell surface engineering is associated with the signal transduction through cell membrane receptors. In signaling process, the signaling appears to emerge from the dynamic motions such as clustering and patterning of distribution of proteins and other molecules in the membrane. Neutrophils were coupled to thermosensitive polymer chains with cell-adhesive RGD peptides. The cells became activated when the temperature was raised. This modification makes it possible to induce the specific activation by clustering of receptors through the polymer association. Nanoparticles can be prepared by the interchain aggregation or the chemical cross-linking of polymer chains. We developed a novel drug delivery system for apoptosis induction by a "smart" polymer vehicle possessing thermo-sensitivity and bioaffinity. The polymeric nanoparticles incorporating an apoptotic inducer, dol-p, were added to a human promonocytic leukemia U937 cell suspension at $37{ }^{\circ} \mathrm{C}$. By lowering temperature to $25{ }^{\circ} \mathrm{C}$, cells underwent apoptosis in the presence of $\mathrm{Ca}^{2+}$. This technique would allow cells to possess the ability to induce apoptosis in response to stimuli such as temperature. Such engineered cells would be expected for the gene therapy, the cytomedical therapy, and the tissue engineering.
\end{abstract}

Key words : cell surface / thermosensitive/RGD peptide / polymer chain/nanoparticle / apoptosis 


\section{1.はじめに}

生体は一つの細胞から発生して分裂することに より数が増え, 臓器および組織が形成される。さ らに組織化が進んで個体が形作られる。その個体 には凝固反応や免疫反応などの精妙で多岐にわた るシステムが存在する。そこには細胞間の認識, 細胞内へのシグナル伝達, 遺伝子発現の活性化, タンパク質の産生抢よび分泌などが起こってい る。このような個体（生体）に対して，何十年か 前に人工材料を用いて医療的行為の補助とするこ とが始まった。それ以来，アナロジー的発想で 様々な臓器に材料は用いられてきた。医学的な評 価はこういった複雑なシステムを内包したまま統 計的に行われる。従ってそこから抽出された生体 適合性は多義的であり，とらえどころのない特性 となってしまった。この生体適合性はバルクの性 質に関する力学的適合性と材料表面の性質に関す る表面適合性とのふたつに分けて考えることがで きる1). 人工血管では周囲の組織と材料との力学 的なつり合い(力学的適合性) が重要となってく る。人工物と生体との接合部のマッチングが悪い と力学的なストレスが発生する. その結果, 生体 が脆弱化して破裂したり，内膜の過形成によって 閉塞が起こったりすることが指摘されている。一 方, 表面適合性という観点からは主として生体シ ステムを活性化させない材料と細胞あるいは組織 に対して親和性をもつ材料の開発が行われてき た。なかでも血液適合性に関する研究が数多くな され，極端に親水性でも疎水性でもない表面には 実験的にも理論的にも血液成分が付着してしまう

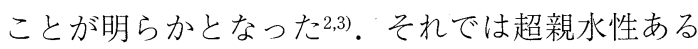
いは超疎水性表面が優れているかというとそんな に単純ではない。ほとんどの材料は短期間の間だ けしか使うことができない。少し長く使う場合に は必ず抗凝固剂などの薬物の助けが必要となる。 一力, 組織に対して親和性を与えるために生体に 似せた表面をつくるという研究が進められてき た。細胞膜表面は脂質の極性部位によって形成さ れている。従って，この表面を真似た材料として リン脂質の極性部位を含有したポリマーが開発さ
れ，優れた血液適合性を示すことが明らかとなっ ている4).

もともと生体表面と人工材料表面との界面は一 つの安定化状態をもつものではないと考えること も大切である. 生体側で起こる動的な变化に材料 側は追随できないと考えると理解しやすいだろ う。生体側と相克するような存在にするためには 材料側に動的な因子を導入することが考えられ る。例としてはタンパク質招よび細胞固定化材料 があげられる。これは生体成分と材料とのハイブ リッド化であり，生体成分が動的因子として材料 に盛り込まれたものと考えられる。ここでは生体 からもらってきたものが生体系の助けをかりて材 料側で再構築される。このような研究の延長とし て今日の再生医療抢よび組織工学がある。これ以 外には材料をナノレベルでデザインすることが考 えられる。細胞のシグナル伝達における分子の構 造変化や会合・脱会合, あるいは細胞の形態変化 や運動の際に見られる, アクチンフィラメント, 微小管, 中間系フィラメントといった細胞骨格系 構造体の形成と破壊はすべてナノレベルである。 生体機能の発現では構造体のナノレベルでの变動 を伴うことが多い. ポリマー鎖はちょうどナノレ ベルのマテリアルであり，生体システムに作用す るようにデザインすることができる材料である。 これは材料の適合化というよりは，材料をナノレ ベルにすることにより生体をうまくだまして良い ことをさせようとするアプローチだと考えられ る、以下にわれわれがポリマー鎖から作ったいく つかのナノバイオマテリアルを紹介する.

\section{2. 細胞の顔を変えるナノチェーン}

生体は複雑で精妙な認識を行っているが, 分子 と分子とが接触してはじめてその物語が進行す る。細胞膜の外側には糖鎖やタンパク質からなる 細胞外皮が存在する。ここでは, 糖鎖, タンパク 質分子，および脂質膜を介して様々でかつ特異的 な認識と応答が起こっている。白血球の遊走では ローリング, 強固な接着, 遊走のそれぞれのステ ップに扔いて接着に関与する生体ポリマーの種類 


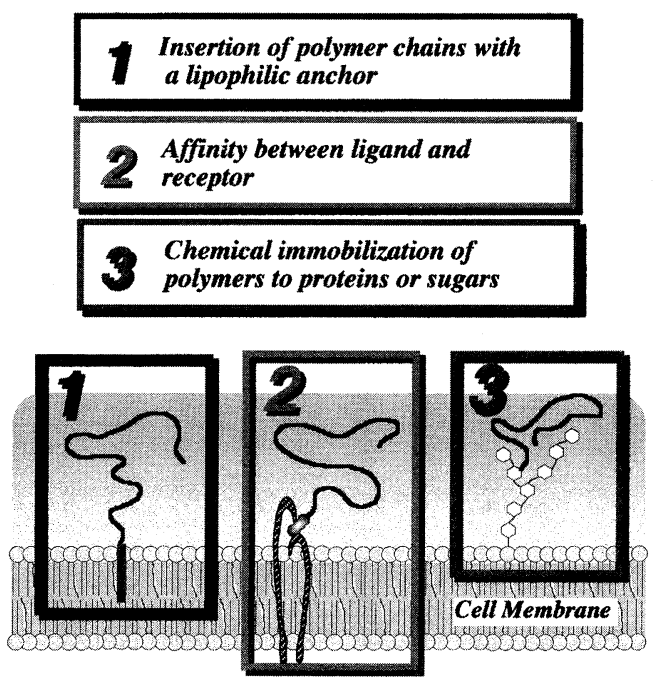

Fig. 1 Approaches to immobilization of polymer chains onto a surface of living cells.

が変わり，白血球と内皮細胞間の距離も次第に近 づいてくる。ここでの生体ポリマーの役割は細胞 間の距離を保つこと，および識別して結合させる ことである。これは細胞の認識において分子間距 離が大切になってくることを示している. 従って, 細胞表層よりも遠い距離に新たな層を創って遮蔽 するか，あるいは表層の認識分子が働かないよう にすることができれば，細胞を無個性にも別の個 性をもつようにも改質できると考えられる5 .

素材化に際して，まず大切なことは人工の外層 をつくることである.Fig. 1にポリマー鎖からなる 層を細胞外につくり出す表面改質の方法を示す. まず，Fig. 1の1に示すように脂質膜内にポリマー 鎖を挿入するために，水溶性ポリマーであるポリ アクリルアミド鎖の末端の片方だけに疎水性アン カー（octadecyl基）を結合させたものを合成した. このポリマー鎖で処理した細胞は凝集素であるト ロンビンを加えても凝集が起こらなかった。これ は細胞の外部に水溶性ポリマー鎖からなる保護層 が形成されてトロンビンがレセプターに結合でき なくなったためである。また，ポリマー鎖が細胞 間の接触を阻害していることも考えられる。

細胞膜上の夕ンパク質あるいは糖鎖にポリマー 鎖を化学結合（Fig. 1の3）させることによっても

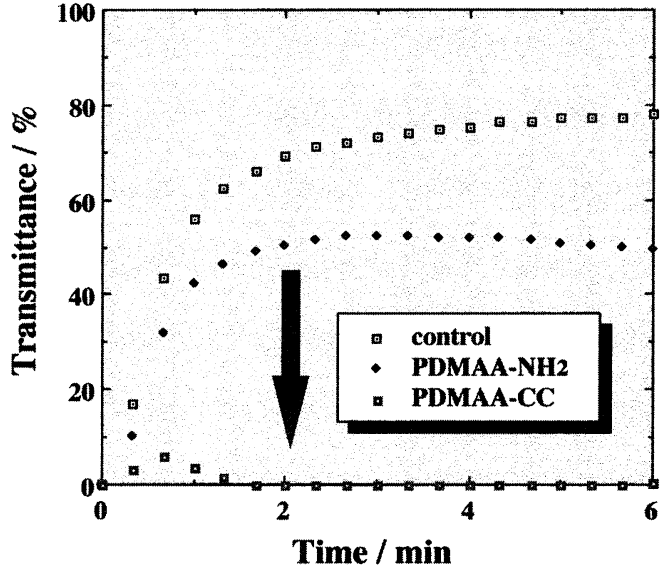

Fig. 2 Time-course of platelets aggregation by thrombin. Reactive (PDMAA-CC) and parent (PDMAA$\mathrm{NH}_{2}$ ) polymers were added at the concentration of $0.187 \mathrm{mM}$ to a cell suspension. The final concentration of thrombin was $0.15 \mathrm{units} / \mathrm{ml}$.

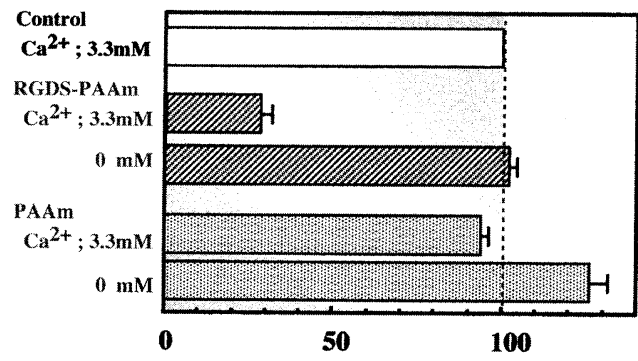

Active oxygen released / \%

Fig. $3 \mathrm{Ca}^{2+}$ dependent active oxygen release from modified neutrophils upon contacting with a PS dish.

Cells were preincubated with RGDS-carrying polymer chains.

保護層をつくることができる。そこでポリマー鎖 の片方の末端のみに塩化シアヌルを有する水溶性 ポリマーを合成した。塩化シアヌルの部分は細胞 外皮に存在する糖鎖の水酸基，あるいは膜タンパ ク質のアミノ基と化学結合することができる。こ の素材を用いて血小板の表面改質を行った場合に も，トロンビン添加に対して凝集が抑制されてい る結果が得られた（Fig. 2)。この反応性ポリマー 鎖を顆粒球に導入することを試みた。顆粒球は体 内に侵入してきた異物を捕らえて排除する機能を もっている。ポリスチレンの微粒子（直径約 


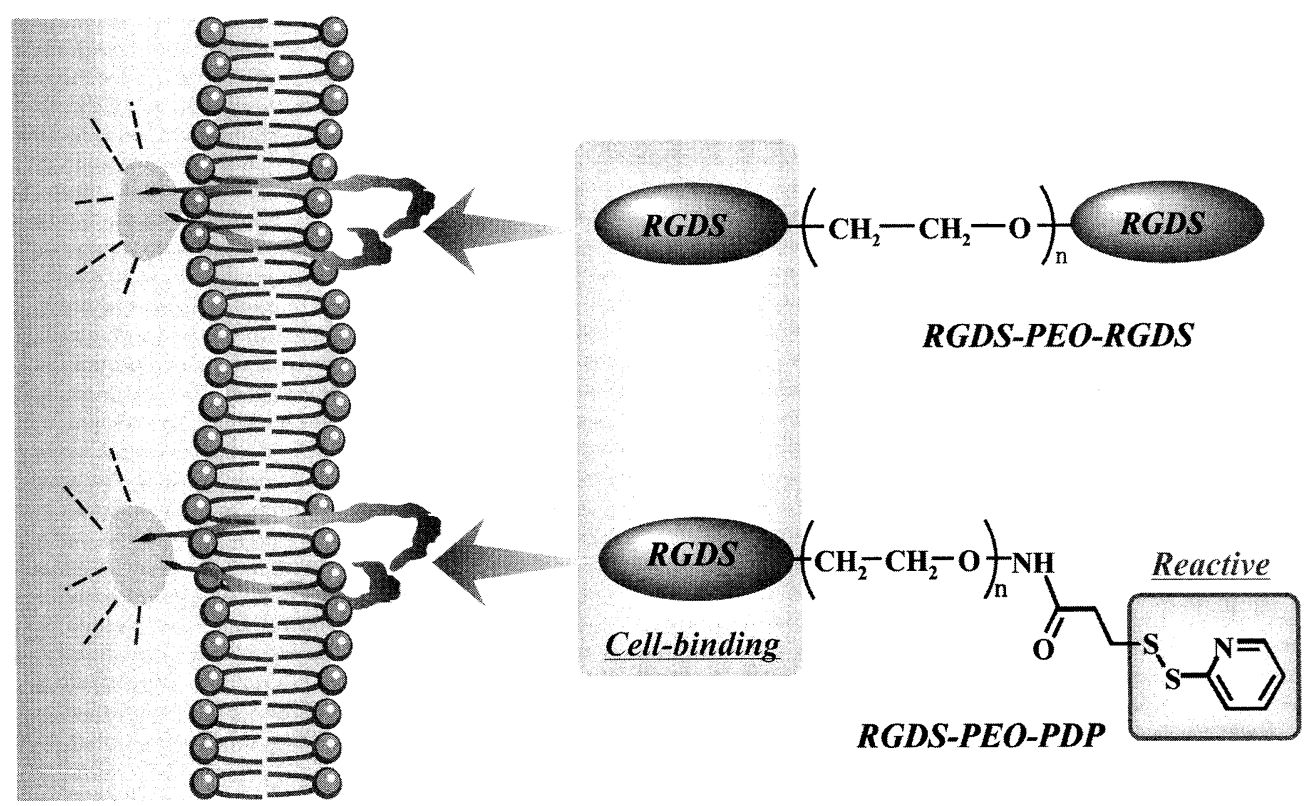

Fig. 4 Cell surface modification by bifunctional polymer chains.

800nm）を顆粒球に加えると，微粒子を宔食して 多量の活性酸素を放出した。ポリマー鎖が結合し た顆粒球の場合には活性酸素の放出量は低くなる 結果となった。このような遮蔽効果を示した濃度 域においては，ポリマー鎖による毒性発現および 細胞の活性化は認められず, 機能低下も起こって いなかった。この活性化の抑制は顆粒球表面の保 護層によって微粒子と細胞とが接触できなくなっ たためだと考えられる。

また，レセプターとリガンドといった細胞の特 異的相互作用を用いてもポリマー保護層を形成さ せることができる（Fig. 1の2）。ポリマー鎖に結合 させるリガンドには，フィブロネクチンなど多く の細胞外マトリックスの構成成分で, 細胞のイン テグリンレセプターと結合するテトラペプチド RGDS（Arg-Gly-Asp-Ser）を選んだ。まず，片方 の末端のみにアミノ基を有するポリマー鎖を合成 し，カルボジイミド法でアミノ基を介してRGDS ペプチドの結合を行った．Fig. 3に示すように RGDSペプチドを介してポリマー鎖を結合させた 顆粒球では活性酸素の産生量が減少し, 異物認識 能の抑制が示唆される結果となった。 RGDSとイ
ンテグリンとの結合はカルシウムイオン存在下で 起こることから, 系のカルシウムイオン濃度を低 下させると再び活性酸素を産生するようになっ た、レセプターを介した表面改質でもシグナル伝 達（この場合はクラスター化）を引き起こさない ものであれば，保護層形成のために用いることが できる。この改質細胞では, 様々な生体物質間の 相互作用が起こらないため異種間での細胞利用 (免疫隔離) に応用できると考えられる。

さらに，ポリマー鎖を結合させることにより細 胞に新たな親和性を導入することもできる。それ によって細胞をデリバリーあるいは集積化するこ とも可能となる. Fig. 4のようにポリエチレンオキ サイドの両末端に細胞接着性ぺプチドRGDSを導 入したポリマー鎖を細胞表面に導入すると，未改 質の細胞との間で凝集塊が形成される。これは細 胞凝集を人為的に制御できることを意味してい る、また，末端に別のリガンドを導入することに より種類の違う別の細胞を捕らえて作用を与える ように細胞を変換することもできる。ささらに化学 反応性を付与すると人工物への細胞の集積化が可 能となる。このような技術により複数の細胞から 
組織体を形成させることや，細胞を人工物に集積 させることも可能となるだろう。細胞はなんとナ ノサイズの一皮で騙されるのである.

\section{3. 細胞機能を制御するナノマテリアル}

シグナル伝達においては，細胞外皮に存在する 糖鎖やタンパク質などを介して特異的な認識と応 答が起こる。この際に脂質膜は分子を局在化させ， かつ高い運動性を与える場となる。そこでは様々 な形やパ夕ーンが生起され，脂質膜はこれらの分 子の運動に変調を与えて巧みな調節を行ってい る. 最近, 細胞外マトリックスの機能の研究から 特異的なシグナル伝達にはレセプターの集合と離 散といった機能分子に扔ける階層性が本質である ことが見えてきた。免疫系でもレセプターの凝集 は重要であり，人工リガンドによってレセプター を凝集させて細胞の機能を活性化させる報告がな されている6).さらに最近， T細胞の活性化にお いて，抗原提示細胞との接着部位がICAM-1を中 央にMHC分子が周りを囲んだパターンを形成し， それが時間とともに変化して最終的にクラスター (免疫シナプス) を形成することがわかってきた7). このようなことから，特定の接着分子のクラス夕 一化を人為的に引き起こして，階層性を形作るこ とにより細胞のもつ特定の機能を誘導できるので はないかと考えられる。モデルとしてインテグリ ンのクラスター化に注目し，RGDSペプチドリガ ンドをポリマー鎖掞よびポリマー微粒子に固定化 した。ここではポリマーがレセプターの凝集を引 き起こすようにある仕掛けをした。このポリマー はポリN-イソプロピルアクリルアミド (PNIPAM) といって，温度を変化させると形態が変化する温 度応答性を有している。つまり，この素材はレセ プターと多点で結合して，温度変化に伴って形態 が収縮することによりレセプターの凝集を引き起 こすことが期待できる（Fig. 5)。まず，RGDSが いくつも結合した温度応答性ポリマー鎖を合成し た。このポリマー鎖を顆粒球と接触させ，系の温 度を $25^{\circ} \mathrm{C}$ から $37^{\circ} \mathrm{C}$ 一と変化させた. $37^{\circ} \mathrm{C}$ への昇温 に伴い細胞から大量の活性酸素が産生された。

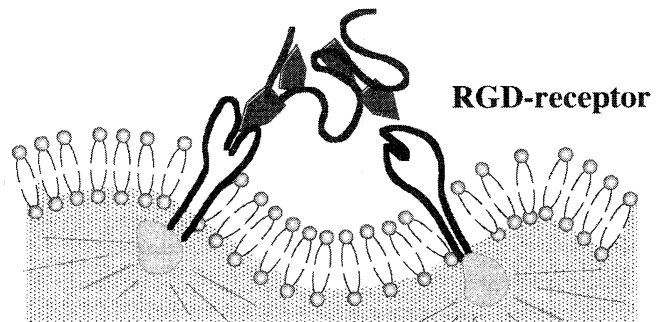

\section{Cytoplasmic}

Domain
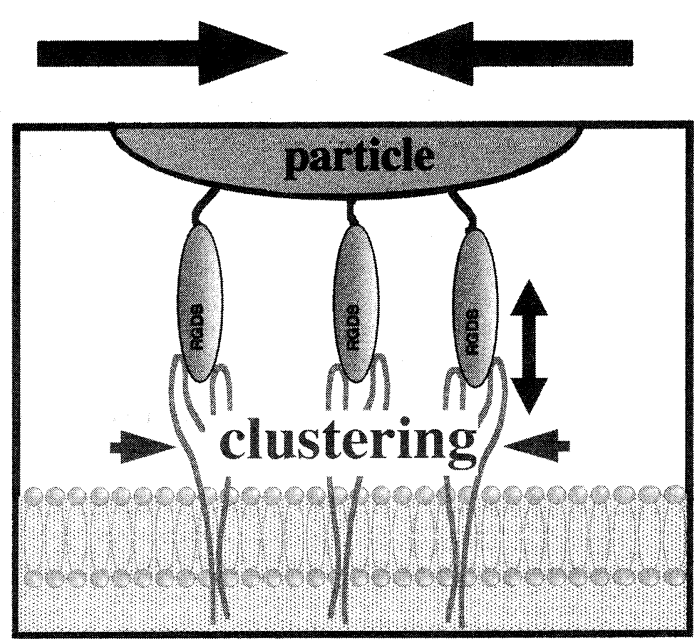

signal transduction

Fig. 5 Control of signal transduction with ligand-carrying polymeric materials.

RGDSペプチドを添加することによりこの産生は 抑制された。確かにRGDSとインテグリンの複合 体が形成されて活性化が起こっていることがわか る。一方，このような活性化は，RGDSペプチド を片末端にだけ導入させたポリマー鎖では認めら れなかった。これは一本のポリマー鎖が多数のリ ガンドを介して多数のレセプターと結合してレセ プターとリガンドの複合体を集合化させることが 必要であることを示唆している。微粒子でも同じ ような素材を創ることができる，微粒子のサイズ

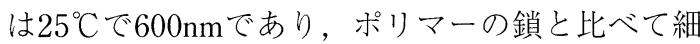
胞との接触面積が飛躍的に広がる。RGDSを固定 化させた微粒子を $25^{\circ} \mathrm{C}$ で細胞に添加すると細胞の 周囲に多数の微粒子がしつかりと付着する。この 


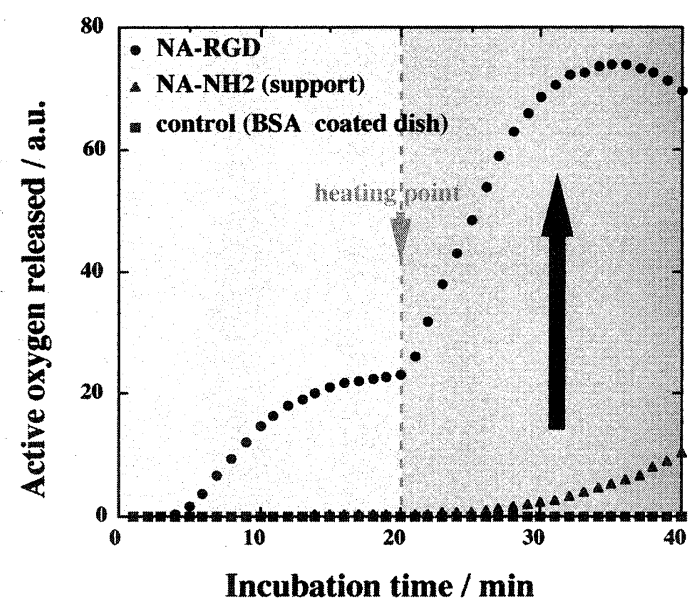

Fig. 6 Time-course of active oxygen production caused by PMNs contacting NA-RGD or NA-NH2 particles. The temperature was changed from $25^{\circ} \mathrm{C}$ to $37{ }^{\circ} \mathrm{C} 20$ min after incubation.

微粒子は昇温に伴ってサイズが $350 \mathrm{~nm}$ 位まで収縮

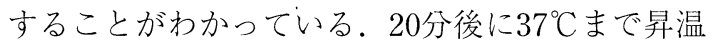
させて活性酸素の産生を調べたところ, ペプチド を導入していない担体微粒子では産生量が非常に 少ないのに対して, RGDS固定化微粒子では過剩 な産生が観察された（Fig. 6)。この微粒子は膨潤 状態 $\left(25^{\circ} \mathrm{C}\right)$ でRGDSペプチドを介してレセプタ 一と多点で接着する。接そらく，この状態から $37^{\circ} \mathrm{C}$ 昇温することにより粒子は収縮し，多数の リガンドーレセプター複合体が集合化されることに より過制のシグナルが入力されたものと考えてい る。これにより細胞に疑似シグナル伝達を行うこ とができるようになる，様々なリガンドを選択す ることにより, 多様な機能の制御へと展開するこ とが期待できる。ナノバイオマテリアルによって 細胞機能を人為的に制御することができる日も近 w.

\section{4. アポトーシスを制御するナノマテリアル}

アポトーシスは高度な制御機能をもった能動的 細胞死であり, 癌や自己免疫疾患などの多くの疾 病の発症に深く関わっていることが明らかになっ
てきている. 最近，いくつかの脂質分子がアポト ーシスを誘導することがわかってきた。このよう な化合物にイソプレノイド化合物がある。この化 合物を特定の有機溶媒に溶解させてヒト単球性白 血病細胞株U937細胞に添加すると, 緩衝液中で 200nm前後のエマルションを形成していた8). アポ トーシス誘導にはエマルション形成が必要であ り，またエマルションが安定すぎても効率が低下 してしまうことがわかった。ささらに，溶液中に血 清アルブミンを加えることにより，アポトーシス 誘導が促進された。溶液中のAlbの二次構造に変 化が認められ, 誘導物質とアルブミンは複合体を 形成していることが示唆された。挔そらく溶液中 でアルブミンは誘導物質を細胞まで運ぶキャリア のような働きをして誘導活性を高めていると考え られる。

そこで，エマルションとアルブミンの代わりに ポリマー鎖を用いて，誘導物質であるドリコール リン酸（Dol-p）を封入したアポトーシス誘導ナノ キャリアの作製を試みた（Fig. 7)。まず，反応性 基をもつ温度応答性のPNIPAM鎖を作製した。こ のポリマー鎖に細胞接着性ペプチドRGDSを導入 して, 細胞接着性と温度応答性を合わせもつポリ マー鎖とした. Dol-pの封入はこのポリマー鎖が溶 解している温度 $\left(31^{\circ} \mathrm{C}\right)$ でDol-pと共存させ, 次に 収縮する温度 $\left(37^{\circ} \mathrm{C}\right)$ まで昇温することにより行

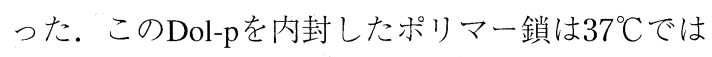
$200 \mathrm{~nm}$ 以下の単一サイズの凝集体となり, 細胞に

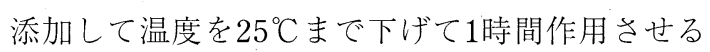
ことにより，DNAの断片化が見られるようになっ た9). 一方, 温度を変化させずDol-pを会合体内に 封入したままの場合にはアポトーシスは誘導され なかった。このナノキャリアは内側に薬剈のため のキャビティをもち, 外側の細胞接着ペプチドを 介して細胞近傍に集積し, 温度変化によってキャ リアの形態が変化して内封物質を細胞膜に効率よ く移行させることができるものと考えられる。こ れは温度変化により人為的に細胞を死に至らしめ る技術であり, 細胞性製郕や組織工学にも利用可 能だと考えている。 


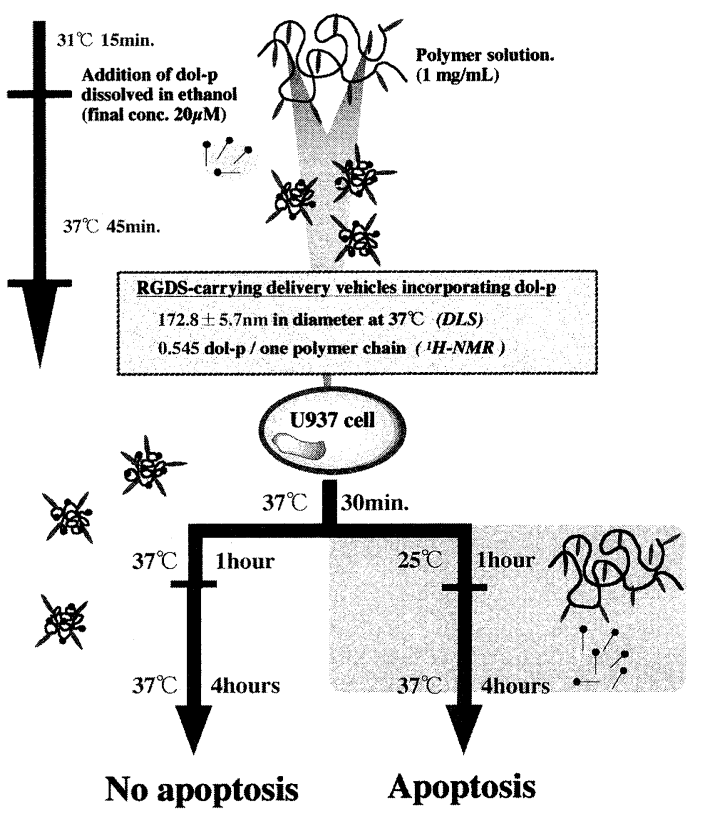

Fig. 7 Schematics of the drug delivery system for apoptosis induction using the smart polymeric vehicle. Targeting sites (e.g. RGDS) can be given to the copolymer chain by immobilizing various ligands. Above their lower critical solution temperature (LCST), the association of the copolymer leads to stable aggregates formed mainly through the packing of individual collapsed chains. The nanoscale delivery vehicle possesses the hydrophobic cavity for the incorporation of lipid inducers of apoptosis. The release of lipid inducers of apoptosis from the cavity is triggered by the disruption of vehicles by lowering temperature. The released inducers are transferred to the cell membrane, leading to apoptosis induction.

\section{5. 最後に}

細胞をはじめとする生体系での新しい知見が 次々と明らかとなり, 我々のような高分子研究者 からもそこをターゲットとした研究が可能となっ てきた．生体系に対して様々な働きかけをする素 材を合成することよって，生体機能を制御できる
可能性を示唆しているように思われる。これから は，材料を生体系に融合させるように設計し実際 に作製することがますます重要になってくると思 われる。しかし，単に生物を真似ただけでは組織 再生，さらに医療への貢献などおぼつかないだろ う. 現段階では生物の不思議さからマテリアルづ くりを考えさせていただいているというところで あろう。ここで紹介した研究はひとつの例である. 当然これ以外にもモデル化は存在しうる。重要な ことは形にすることを思いつくかどうかというこ とであるように思う。

\section{謝 辞}

アポトーシスに関する研究は国立国際医療セン 夕一研究所の大島美恵子先生と八杉悦子先生との 共同研究であり，ここに感謝申し上げます。

\section{文 献}

1) 箋 義人:「高分子新素材One Point 20 , 医用高 分子材料」, 高分子学会編, pp.58-79, 共立出版 (1989)

2) 筏 義人:「バイオマテリアル」, pp.209-224, 日 刊工業新聞社 (1988)

3) 松田武久:「生体コロイド I, 基礎と実際」, 嶋林 三郎, 寺田 弘, 岡林博文編, pp.777-818, 廣川書店 (1990)

4) 中林宣男, 石原一彦, 岩崎泰彦:「バイオマテリア ル」, 日本エム・イー学会編, pp.82-86, コロナ社 (1999)

5) Fujimoto K : "Supramolecular Design for Biological Applications", Yui N ed., Chap. 17, CRC Press, New York (2002)

6) Spencer $D$ M, Wandless $T$ J, Schreiber $S \mathrm{~L}$ and Crabtree G R : Science, 262 1019-1024 (1993)

7) Grakoui A, Bromley S K, Sumen C, Davis M M, Shaw A S, Allen P M and Dustin M L, : Science, 285 221-227 (1999)

8) Fujimoto $\mathrm{K}$, Iwasaki $\mathrm{C}$, Kawaguchi $\mathrm{H}$, Yasugi E, and Oshima M : FEBS Letters, 446 113-116 (1999)

9) Fujimoto K, Iwasaki C, Arai C, Kuwako M, Yasugi E : Biomacromolecules, 1 515-518 (2000)

（受付 2002年9月5日 掲載決定 9月14日） 